\title{
16. DOCUMENTING TEXTURES AND MINERAL ABUNDANCES IN MINICORES FROM THE TAG ACTIVE HYDROTHERMAL MOUND USING X-RAY COMPUTED TOMOGRAPHY1
}

\author{
Margaret Kingston Tivey ${ }^{2}$
}

\begin{abstract}
X-ray computed tomography $(\mathrm{CT})$ was used to image four $2.5-\mathrm{cm}$ diameter minicores of material recovered from within the Trans-Atlantic Geotraverse (TAG) active hydrothermal mound. CT images allow examination of textural relationships among clasts, veins, and matrix of pyrite-silica, pyrite-silica-anhydrite, and pyrite-anhydrite breccias, estimation of mineral abundances, and extrapolation of observations made on two-dimensional thin sections to the scale of 2 to $3 \mathrm{~cm}$ in three dimensions. Information on mineral abundances, coupled with shipboard porosity measurements, was used to estimate the thermal conductivity of each minicore. Estimated values agree with measured values. Reasonable fits of estimated and measured thermal conductivities allow extrapolation of thermal conductivities of minicores to in situ conditions $\left(\sim 350^{\circ} \mathrm{C}\right)$.
\end{abstract}

\section{INTRODUCTION}

The Trans-Atlantic Geotraverse (TAG) active hydrothermal mound is a $200-\mathrm{m}$ diameter feature located at $3670 \mathrm{~m}$ depth within the larger TAG hydrothermal field at $26^{\circ} 08 \mathrm{~N}$ on the Mid-Atlantic Ridge. Its geologic and tectonic settings are discussed in detail by Rona et al. (1993) and Kleinrock et al. (1996). The mound exhibits $\sim 50 \mathrm{~m}$ of relief, rising above pillow lavas that are covered by a layer of pelagic carbonate sediments up to a meter thick. The surface of the mound is comprised of a range of hydrothermally precipitated rock types, including black smoker chimneys, white smoker chimneys, and blocks of massive anhydrite, Fe-rich massive sulfide, and ocherous Fe-oxide (Tivey et al., 1995; Thompson et al., 1988). There are two distinct, but related, fluid compositions exiting the mound; fluids exhibiting temperatures up to $366^{\circ} \mathrm{C}$ exit the mound from the Black Smoker Complex in the northwest quadrant of the mound, and lower temperature $\left(273^{\circ}-301^{\circ} \mathrm{C}\right)$ fluids flow less vigorously from a field of white smokers, termed the "Kremlin" area, located $\sim 70$ m southeast of the Black Smoker Complex (Edmond et al.,1995; Thompson et al., 1988). A number of studies have been carried out to characterize samples recovered from the surface of the mound (e.g., Thompson et al., 1988; Rona et al., 1993; Tivey et al., 1995; Lalou et al., 1990, 1993; Hannington et al., 1988; Herzig et al., 1991; Edmond et al., 1995; Mills and Elderfield, 1995; Mitra et al., 1994). Investigations addressing subsurface portions of the mound include magnetic, heat flow, gravity, electromagnetic, and geoelectrical studies (Tivey et al., 1993; Becker and Von Herzen, 1996; Evans et al., 1993; Evans, 1995; Von Herzen and Kirkland, 1993).

During Leg 158 of the Ocean Drilling Program, samples were recovered from within and below the mound. Holes were drilled in five areas, to a maximum of $125 \mathrm{mbsf}$ at the TAG-1 area, $20 \mathrm{~m}$ southeast of the Black Smoker Complex (Fig. 1; Humphris et al., 1995). Recovered material includes massive sulfide, red and gray siliceous materi$\mathrm{al}$, and sequences of sulfide-sulfate-silicate, sulfide-silicate, silicified wallrock, and chloritized basalt breccias (Humphris et al., 1995; Humphris, Herzig, Miller, et al., 1996). The breccias are texturally complex, composed of mixtures of different clast types, and exhibit

${ }^{1}$ Herzig, P.M., Humphris, S.E., Miller, D.J., and Zierenberg, R.A. (Eds.), 1998. Proc. ODP, Sci. Results, 158: College Station, TX (Ocean Drilling Program).

${ }^{2}$ Department of Marine Chemistry and Geochemistry, Woods Hole Oceanographic Institution, Woods Hole, MA 02543, U.S.A.mktivey@whoi.edu variable proportions of clasts, matrix, and veins. Some breccias are matrix-supported, whereas others are clast-supported.

An understanding of the three-dimensional geometry of breccia clasts, matrix, and veins will help in deducing how the mound evolved, and aid in interpretation of physical properties measurements and data from geophysical experiments. A number of minicores were taken from representative sections of core and used to measure density, porosity, thermal conductivity using a half-space method, compressional wave velocity, electrical resistivity, and seismic velocity (Humphris, Herzig, Miller, et al., 1996). X-ray computed tomography (CT, or CAT scanning) was used as a noninvasive and nondestructive tool to image 4 of these minicores to determine the relative proportions and distributions of phases.

\section{METHODS}

X-ray CT was used to image clasts, matrix, veins, and pore space in four $2.5-\mathrm{cm}$ diameter cylindrical minicores composed of sulfide (density 4.1 to $5.02 \mathrm{~g} / \mathrm{cm}^{3}$ ), anhydrite (density 2.9 to $3.0 \mathrm{~g} / \mathrm{cm}^{3}$ ), and quartz (density $2.65 \mathrm{~g} / \mathrm{cm}^{3}$; Deer et al., 1966). The density contrasts between these materials and air make it possible to use X-ray CT as an effective imaging tool. A third-generation industrial CT scanner, with a 5- $\mu \mathrm{m}$ spot design microfocus tube, was used. In this system, the sample is rotated inside an area bounded by an X-ray source and an array of detectors. A $160-\mathrm{kVp}, 0.22-\mathrm{mA}$ source was used, with beam energy shifted from 3 layers of $\mathrm{Cu}$, each $0.63 \mathrm{~mm}$ thick, resulting in a beam with an average energy of $>80 \mathrm{keV}$. The system uses a 9-in trifield image intensifier (operated in 6-in mode) and a SONY xc77 solid state CCD camera; magnification is $\sim 5 \times$, with the source image and source object distances $535 \mathrm{~mm}$ and $105 \mathrm{~mm}$, respectively. Slice thickness is $100 \mu \mathrm{m}$, and the horizontal voxel dimension is $\sim 50$ $\mu \mathrm{m}$. All objects were imaged in air.

In X-ray CT, X-rays are absorbed along each path according to the electron density encountered, and, for a monoenergetic source, the intensity is reduced according to the linear attenuation coefficient. As the sample is rotated, total X-ray attenuation is measured for each transmitted ray, and a two-dimensional image, or cross-sectional slice, is reconstructed with voxel values proportional to the linear attenuation coefficients (Bates et al., 1983; Orsi and Anderson, 1994). In this study, where a polyenergetic source was used, the voxel values of the CT image are not strictly proportional to the linear attenuation coefficients since the linear attenuation coefficients are energy dependent. Voxel values are thus referred to here as CT densities. In ad-

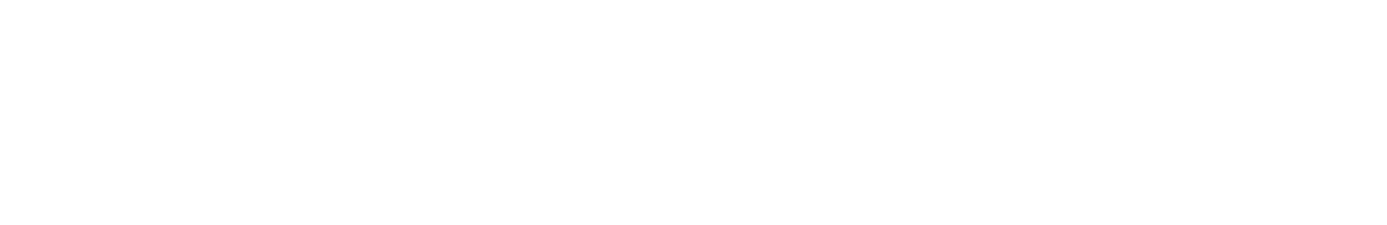




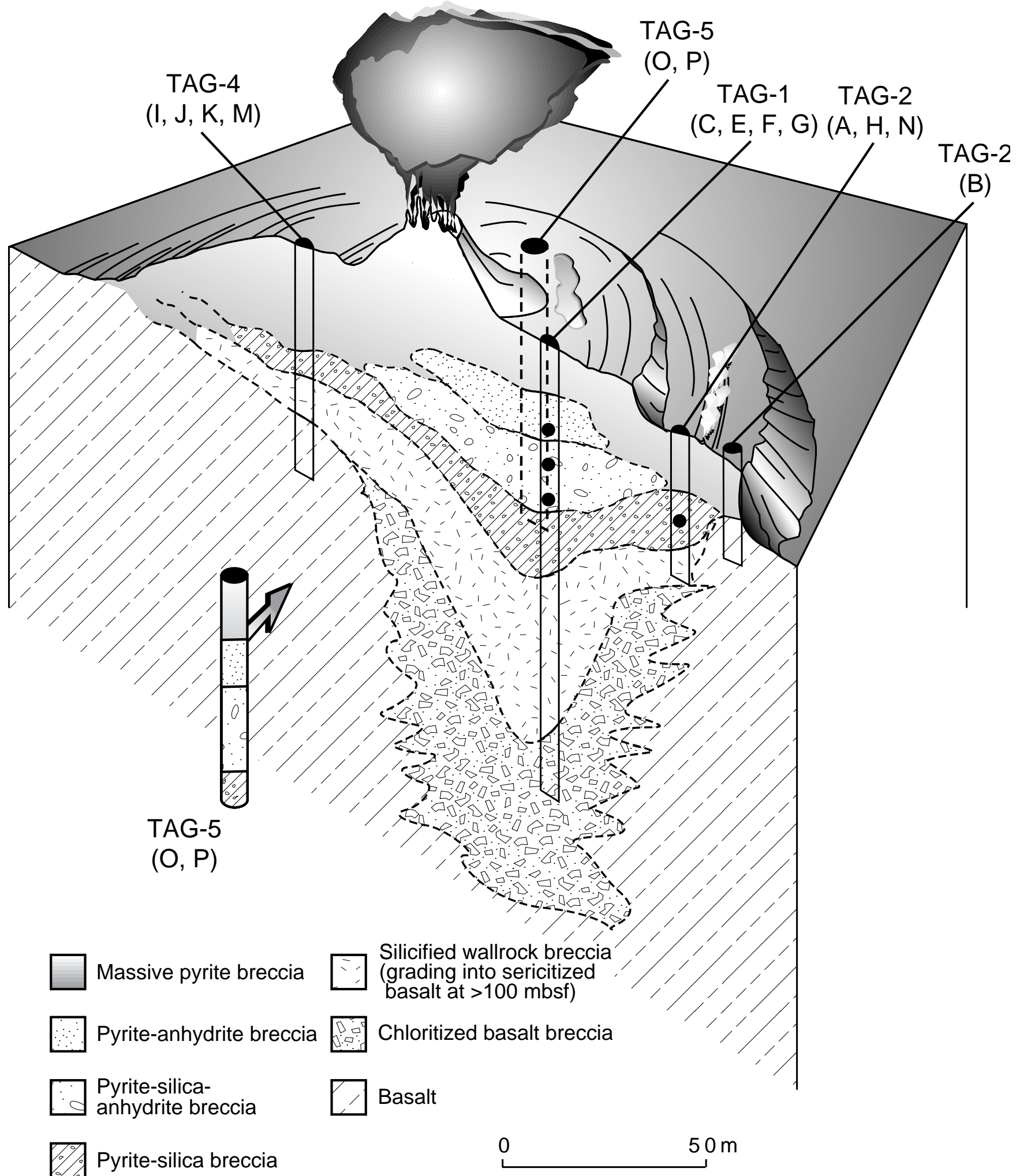

Figure 1. Diagram of the TAG active hydrothermal mound showing the distribution of venting at the surface, the surface morphology, the location of drilling areas TAG-1 through TAG-5, and a schematic view of the internal structure of the mound based on drilling results (from Humphris et al., 1995). Locations of samples used in the CT study are indicated by the solid circles. 
dition, CT images were reconstructed against a standard to minimize artifacts from beam hardening (an effect caused by the preferential absorption of lower energy X-rays along the path, resulting in attenuation coefficients of the same material having different values depending on distance from the source) and X-ray scattering. An aluminum cylinder of similar diameter and density to the cylindrical minicore samples was scanned, and the logarithm of the intensity of the readings of this standard was subtracted from those of the minicore sample during image reconstruction. As shown in Figure 2, this technique was sufficient to remove the "cupping" effect.

The output array of CT densities $(512 \times 512$ matrix $)$ can be displayed graphically. CT densities span the range 0 to 4096. Multiple two-dimensional images are stacked to create vertical slices. Spatial resolution of the CT images was determined by examining CT density values across sharp edges between solid sulfide and air. Calibration of CT density values to the composition of the minicores was accomplished by comparing CT data with observations of $\sim 100-\mu \mathrm{m}-$ thick petrographic thin sections made from each minicore that correspond with scanned locations.

The minicores chosen for study display a range of mineralogy and porosity. Sample locations are shown in Figure 1, and the measured porosity of each minicore is shown in Table 1. All CT scans were made perpendicular to the cylindrical axes of the samples. Two sets of 21 scans, one taken at $1-\mathrm{mm}$ vertical intervals, and one at $0.1-\mathrm{mm}$ vertical intervals, were made from each sample. The set of $0.1-\mathrm{mm}$ spaced scans allows construction of contiguous $2.1-\mathrm{mm}$ vertical slices, since slice thickness is $0.1 \mathrm{~mm}$. The set of 1-mm-spaced scans allows construction of vertical slices for the full length of samples. Polished thin sections $(\sim 100 \mu \mathrm{m}$ thick) were made from portions of samples represented by the contiguous set of scans.

\section{COMPARISON OF CT IMAGES WITH PETROGRAPHIC THIN SECTIONS}

Images of the thin sections and the closest corresponding CT images are displayed in Figure 3. The CT images and thin sections do not precisely correspond to one another owing to slight angling during thin-section preparation (i.e., the thin sections were not taken exactly perpendicular to the axes of the cylindrical samples). Thin-section descriptions are given in Table 2. Comparison of thin sections with the best corresponding CT image was used to determine critical CT density values, $\alpha_{p}$ and $\alpha_{s}$, that correspond to upper limits of $100 \%$ pore space, and lower limits of predominantly sulfide, respectively. The threshold value for $\alpha_{p}$ was determined by finding the largest value that would not result in areas containing anhydrite or quartz from being incorrectly identified as pore space. For all samples this value was 750. The threshold value of $\alpha_{\mathrm{s}}$ was determined by bisecting the maximum gradient observed in plots of CT densities across sulfide/ anhydrite and sulfide/quartz boundaries (see Fig. 2). This value was approximately 1750 for all samples. Owing to the steepness of the gradients (e.g., see Fig. 2), varying this value by \pm 150 does not greatly affect estimates of mineral abundances. Values intermediate between 750 and 1750 correspond to anhydrite, quartz, or mixtures of these phases and minor amounts of pore space and/or sulfide. These values were used for $\alpha_{\mathrm{p}}$ and $\alpha_{\mathrm{s}}$ when processing the CT scans displayed in Figure 3.

As can be seen by comparing the processed CT images with the thin-section images, the distribution of sulfide is well matched using $\alpha_{s}$ of 1750 . Sulfide-dominated areas are composed of primarily pyrite. Owing to the spatial resolution, it is not possible to distinguish in CT images whether voxels of lower CT density values in sulfidedominated areas are void, or filled with anhydrite or quartz. Percent estimates of pore space vs. quartz vs. anhydrite within sulfide-dominated clasts are based on thin-section observations.

Porosity is underestimated in CT images owing to the $\sim 350-\mu \mathrm{m}$ spatial resolution of the CT images. Smaller pores, present dominant-
Table 1. Minicores used in the X-ray computed tomography study.

\begin{tabular}{clrr}
\hline $\begin{array}{c}\text { Core, section, } \\
\text { interval }(\mathrm{cm})\end{array}$ & \multicolumn{1}{c}{ Sample type } & $\begin{array}{r}\text { Depth } \\
(\mathrm{mbsf})\end{array}$ & Porosity* \\
\hline $158-957 \mathrm{C}-$ & & & \\
$7 \mathrm{~N}-3,47-49$ & Nodular pyrite-anhydrite breccia & 22.82 & $15.9 \%$ \\
$11 \mathrm{~N}-2,22-24$ & Pyrite-silica-anhydrite breccia & 32.33 & $4.5 \%$ \\
$14 \mathrm{~N}-1,18-20$ & Pyrite-silica breccia & 40.38 & $3.6 \%$ \\
$158-957 \mathrm{H}-$ & & & \\
$5 \mathrm{~N}-1,33-35$ & Pyrite-silica breccia & 27.03 & $8.9 \%$ \\
\hline
\end{tabular}

Note: $*$ = shipboard measurements, using method C (Humphris, Herzig, Miller, et al., 1996)

A CT image of $\mathrm{C} 7, \mathrm{z}=16 \mathrm{~mm}$
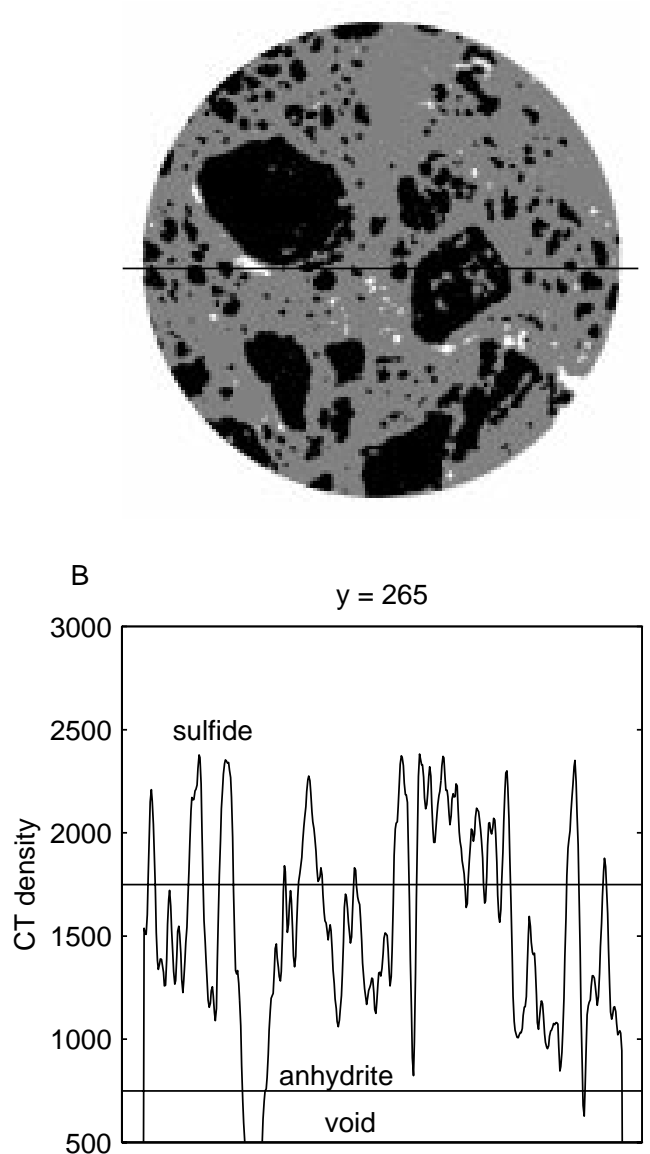

Figure 2. A. CT image of minicore Sample 158-957C-7N-3 (C7). B. Profile of CT density values along the line $\mathrm{y}=325$, indicated by the horizontal line in Figure 2A. CT densities greater than 1749 correspond to predominantly sulfide, whereas those less than 750 indicate pore space, and intermediate values indicate either quartz or anhydrite \pm small amounts of pore space.

ly in anhydrite-rich areas, or along boundaries of clasts, are difficult to discern in these heterogeneous samples because their presence results only in a slight lowering of the CT density value of the voxel. For example, the similarity of CT density values for quartz-dominated vs. anhydrite-dominated areas in the breccias is likely a result of fine pores in anhydrite which lower its density. This hypothesis is supported by petrographic observations that show quartz grains are intergrown with little to no pore space, whereas anhydrite grains exhibit some alteration at grain boundaries as well as small interstitial pores. When large euhedral crystals of these minerals are imaged separately, quartz exhibits CT densities lower than anhydrite. 

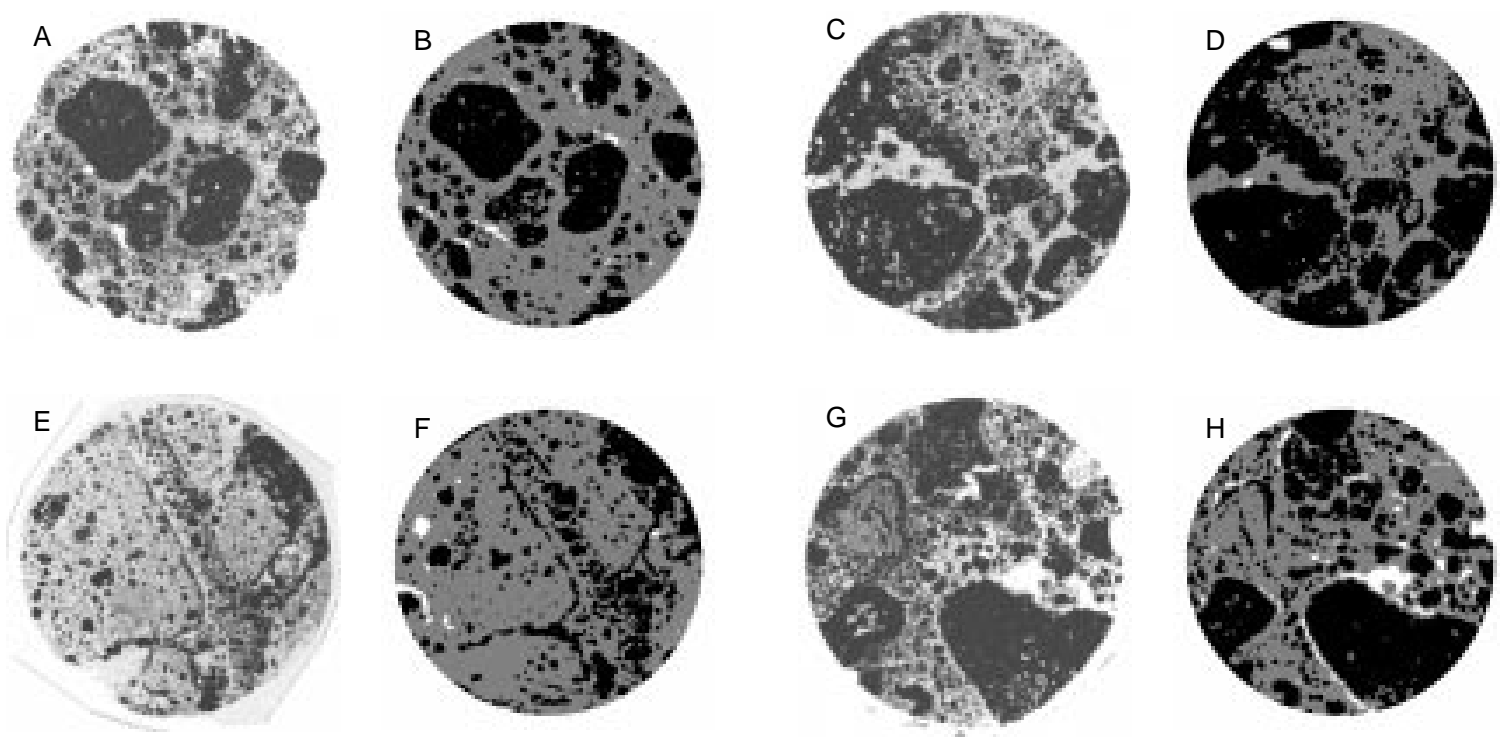

Figure 3. Images of petrographic thin sections and corresponding best fit CT scans for minicore Samples 158-957C-7N-3 (A, B), 957C-11N-2 (C, D), 957C$14 \mathrm{~N}-1(\mathbf{E}, \mathbf{F})$, and $957 \mathrm{H}-5 \mathrm{~N}-1$ (G, H). In the CT images, white areas correspond to voids, black areas to sulfide, and gray areas to quartz and/or anhydrite \pm small pores or grains of sulfide.

Table 2. Thin-section descriptions.

\begin{tabular}{|c|c|c|c|c|}
\hline $\begin{array}{l}\text { Core, section, } \\
\text { interval }(\mathrm{cm})\end{array}$ & Sulfide & Quartz & Anhydrite & Porosity \\
\hline $\begin{array}{l}158-957 \mathrm{C}- \\
7 \mathrm{~N}-3,47-49\end{array}$ & $\begin{array}{l}40 \% \text {. As } 200-\mu \mathrm{m} \text { to } 10-\mathrm{mm} \text { aggregates of } 100-\text { to } \\
300-\mu \mathrm{m} \text { grains, } \sim 20 \% \text { chalcopyrite, } 80 \% \text { pyrite; } \\
\sim 50 \% \text { of } 40-\text { to } 700-\mu \mathrm{m} \text { interstices filled with } \\
\text { quartz, anhydrite, or clay(?). Also as } 50-\text { to } 150- \\
\mu \mathrm{m} \text { subhedral to euhedral pyrite (+ chalcopyrite) } \\
\text { in anhydrite matrix. }\end{array}$ & $\begin{array}{l}2 \% \text { to } 5 \% \text {. In pyrite-dominated } \\
\text { aggregates as anhedral to euhedral } \\
\text { grains up to } 200 \mu \mathrm{m} \text { long. }\end{array}$ & $\begin{array}{l}55 \% \text { to58\%. Intergrown } 100-\text { to } \\
400-\mu \mathrm{m} \text { grains with slightly } \\
\text { altered grain boundaries. Likely } \\
\text { includes } 11 \% \text { of voids as very } \\
\text { fine pores. }\end{array}$ & $\begin{array}{l}5 \% \text { (visual estimate). } 1.3 \% \\
\text { (estimate of large voids by CT), } \\
16 \% \text { (shipboard). }\end{array}$ \\
\hline $14 \mathrm{~N}-01,18-20$ & $\begin{array}{l}29 \% \text {. As aggregates of } 50-\mu \mathrm{m} \text { to } 1-\mathrm{mm} \text { grains } \\
\text { intergrown with quartz, as } 50-\mu \mathrm{m} \text { to } 1-\mathrm{mm} \\
\text { individual grains within quartz dominated clasts, } \\
\text { as grains making up } 500-\mu \mathrm{m} \text {-wide, } \\
\text { semicontinuous rims on some quartz-dominated } \\
\text { clasts, and as } 20 \text { - to } 500-\mu \mathrm{m} \text { subhedral grains in } \\
\text { anhydrite veins; sulfide is } 98 \% \text { pyrite, } 2 \% \\
\text { chalcopyrite. }\end{array}$ & $\begin{array}{l}46 \% \text {. As intergrown } 20 \text {-to } 100-\mu \mathrm{m} \\
\text { grains in } 1 \text { - to } 20 \text {-mm clasts of quartz } \\
(70 \%) \text { and sulfide }(30 \%) \text {, and in pyrite- } \\
\text { dominated aggregates. }\end{array}$ & $\begin{array}{l}22 \% \text {. As veins or matrix } \\
\text { comprised of } 100-\mu \mathrm{m} \text { - to } 2-\mathrm{mm}- \\
\text { long intergrown anhydrite } \\
\text { grains, } 20 \text { - to } 500-\mu \mathrm{m} \text { subhedral } \\
\text { pyrite grains, and } 1-\mathrm{mm} \text { clasts } \\
\text { of quartz + sulfide. }\end{array}$ & $\begin{array}{l}3 \% \text { (visual estimate), } 1 \% \\
\text { (estimate of large voids by CT), } \\
3.6 \% \text { (shipboard). }\end{array}$ \\
\hline
\end{tabular}

Processing of the CT images to show large pores as $<750$, sulfide as $>1749$, and quartz plus anhydrite with micropores as filling areas with CT densities of 750 to 1749 allows calculation of relative abundances of minerals and large voids. These estimates are shown in Table 3. Such processing also allows examination of clast shape and distribution of matrix and veins. Vertical slices can be constructed by stacking two-dimensional CT images.

\section{NODULAR PYRITE-ANHYDRITE BRECCIA, SAMPLE 158-957C-7N-3, 47-49 cm}

Figure 4 shows both horizontal (Fig. 4A) and vertical slices (constructed by stacking 0.1 -mm-thick slices every $1 \mathrm{~mm}$ [Fig. 4B], or ev- ery $0.1 \mathrm{~mm}$ [Fig. 4C]) through minicore sample 158-957C-7N-3, 47$49 \mathrm{~cm}$ (C7). As noted in the thin-section description for this sample (Table 2), sulfide is present as aggregates, and as grains in an anhydrite matrix. Quartz is only found in pyrite-dominated aggregates. The compilation of multiple horizontal and vertical CT images of the core allows generalizations to be made about clast shape and interconnectivity, and about distribution of matrix and veins. As shown in Figure 4, sulfide aggregates are subround and are separated from each other by a matrix of anhydrite that ranges in thickness from $\sim 1$ to $3 \mathrm{~mm}$. Ranges of percents of sulfide, anhydrite plus quartz, and large voids calculated from images shown in Figure 4 are 26 to 40 vol\%, 56 to $71 \mathrm{vol} \%$, and 1 to 4 vol\%, respectively. Approximately 5 vol\% of the quartz plus anhydrite is estimated to be quartz within sul- 
Table 3. Estimated relative abundances of minerals and large pores.

\begin{tabular}{|c|c|c|c|}
\hline $\begin{array}{l}\text { Core, section, } \\
\text { interval }(\mathrm{cm})\end{array}$ & Sulfide & $\begin{array}{l}\text { Quartz + } \\
\text { anhydrite }\end{array}$ & Large pores \\
\hline \multicolumn{4}{|l|}{$158-957 \mathrm{C}-$} \\
\hline $\begin{array}{l}\quad \mathrm{N}-3,47-49 \\
4 \mathrm{~mm} \text { from base }\end{array}$ & 0.31 & 0.65 & 0.04 \\
\hline $8 \mathrm{~mm}$ from base & 0.37 & 0.62 & 0.01 \\
\hline $16 \mathrm{~mm}$ from base & 0.34 & 0.65 & 0.01 \\
\hline $20 \mathrm{~mm}$ from base & 0.26 & 0.71 & 0.03 \\
\hline$x=200$, vertical & 0.34 & 0.62 & 0.04 \\
\hline$x=312$, vertical & 0.40 & 0.56 & 0.04 \\
\hline $\mathrm{y}=200$, vertical & 0.38 & 0.59 & 0.03 \\
\hline $\mathrm{y}=312$, vertical & 0.30 & 0.66 & 0.04 \\
\hline Average vertical & 0.36 & 0.61 & 0.03 \\
\hline \multicolumn{4}{|l|}{$11 \mathrm{~N}-2,22-24$} \\
\hline $3 \mathrm{~mm}$ from base & 0.35 & 0.65 & 0.0 \\
\hline $13 \mathrm{~mm}$ from base & 0.63 & 0.37 & 0.0 \\
\hline $18 \mathrm{~mm}$ from base & 0.71 & 0.29 & 0.0 \\
\hline $23 \mathrm{~mm}$ from base & 0.56 & 0.41 & 0.02 \\
\hline$x=200$, vertical & 0.67 & 0.33 & 0.0 \\
\hline$x=312$, vertical & 0.49 & 0.51 & 0.0 \\
\hline $\mathrm{y}=200$, vertical & 0.51 & 0.49 & 0.0 \\
\hline$y=312$, vertical & 0.63 & 0.37 & 0.0 \\
\hline Average vertical & 0.575 & 0.425 & 0.0 \\
\hline \multicolumn{4}{|l|}{$14 \mathrm{~N}-1,18-20$} \\
\hline $2 \mathrm{~mm}$ from base & 0.16 & 0.82 & 0.02 \\
\hline $12 \mathrm{~mm}$ from base & 0.31 & 0.69 & 0.01 \\
\hline $17 \mathrm{~mm}$ from base & 0.30 & 0.69 & 0.01 \\
\hline $22 \mathrm{~mm}$ from base & 0.31 & 0.67 & 0.03 \\
\hline $\mathrm{x}=200$, vertical & 0.25 & 0.73 & 0.02 \\
\hline$x=312$, vertical & 0.33 & 0.66 & 0.01 \\
\hline$y=200$, vertical & 0.32 & 0.67 & 0.01 \\
\hline $\mathrm{y}=312$, vertical & 0.30 & 0.69 & 0.01 \\
\hline Average vertical & 0.30 & 0.69 & 0.01 \\
\hline \multicolumn{4}{|l|}{$158-957 \mathrm{H}-$} \\
\hline \multicolumn{4}{|l|}{$5 \mathrm{~N}-1,33-35$} \\
\hline $3 \mathrm{~mm}$ from base & 0.19 & 0.76 & 0.05 \\
\hline $8 \mathrm{~mm}$ from base & 0.29 & 0.68 & 0.04 \\
\hline $13 \mathrm{~mm}$ from base & 0.32 & 0.67 & 0.01 \\
\hline $23 \mathrm{~mm}$ from base & 0.54 & 0.40 & 0.06 \\
\hline $\mathrm{x}=200$, vertical & 0.39 & 0.58 & 0.03 \\
\hline $\mathrm{x}=312$, vertical & 0.39 & 0.56 & 0.05 \\
\hline $\mathrm{y}=200$, vertical & 0.32 & 0.65 & 0.03 \\
\hline $\mathrm{y}=312$, vertical & 0.41 & 0.57 & 0.02 \\
\hline Average vertical & 0.38 & 0.59 & 0.03 \\
\hline
\end{tabular}

fide aggregates based on thin-section observations. The estimate of large voids is significantly less than the reported shipboard porosity. It is most likely that the difference can be attributed to fine pores within the anhydrite matrix.

\section{PYRITE-SILICA-ANHYDRITE BRECCIA, SAMPLE 158-957C-11N-2, 22-24 cm}

The texture and abundances of minerals in minicore sample 158957C-11N-2, 22-24 cm (C11) are considerably different than in minicore C7. Based on estimates from the CT images shown in Figure 5 , sulfide composes 35 to 71 vol\% of the sample. Large voids account for less than $2 \mathrm{vol} \%$, and quartz plus anhydrite composes 29 to $65 \mathrm{vol} \%$. Based on thin-section observations, roughly half of the material identified as quartz + anhydrite is assumed to be anhydrite. Instead of being embedded in a matrix, sulfide-dominated and quartzdominated clasts are separated from each other by 0.5 - to 3-mm-wide veins of anhydrite. The distinction between anhydrite and quartz-rich areas is based on observations from the thin section that anhydrite veins are relatively free of sulfide, whereas quartz-rich areas consist of quartz intergrown with pyrite. Using this criterion, it can be seen in Figure 5 that some anhydrite veins are continuous vertically through the minicore. In some places pyrite appears to be continuous through the length of the core, though the 1-mm spacing between horizontal slices means that 0.5 -mm-wide veins separating clasts do not show up in vertical slices. Taking into account that textures are consistent with the entire sample being composed of clasts separated by thin veins, it is likely that pyrite is not connected along the full length of the core. As can be seen in the horizontal CT scans, some clasts appear to have been fractured, and these fractures are now filled with anhydrite. This texture is markedly different than that in minicore $\mathrm{C} 7$.

\section{PYRITE-SILICA BRECCIA, SAMPLE 158-957C-14N-1, 18-20 cm}

Minicore sample $158-957 \mathrm{C}-14 \mathrm{~N}-1,18-20 \mathrm{~cm}(\mathrm{C} 14)$ is a pyritesilica breccia with thin veins of anhydrite separating large (1 to 20 $\mathrm{mm}$ ) angular to subround quartz-dominated clasts. The abundance of pyrite is considerably less than in minicore $\mathrm{C} 11$, ranging from 16 to $33 \mathrm{vol} \%$. Owing to the presence of pyrite grains and aggregates in both anhydrite veins and quartz matrix, it is difficult to distinguish quartz clasts from anhydrite-rich veins in CT images. In some horizontal cross sections, pyrite grains and aggregates are separated from each other by quartz and/or anhydrite, while in other horizontal cross sections relatively continuous bands of pyrite provide outlines of clasts (Fig. 6). In vertical slices constructed by stacking horizontal CT images, pyrite and quartz/anhydrite appear to be interconnected in some places along the length of the core. Again, the 1-mm spacing between horizontal slices can prevent thin $(<1 \mathrm{~mm})$ veins or portions of matrix, or small grains $(<1 \mathrm{~mm})$, from showing up in the vertical cross sections. Ranges of percents of anhydrite + quartz and large voids in vertical slices are 66 to $82 \mathrm{vol} \%$ and 1 to $3 \mathrm{vol} \%$, respectively. Based on thin-section observation, it is assumed that approximately $1 / 3$ of the anhydrite + quartz is anhydrite.

\section{PYRITE-SILICA BRECCIA, SAMPLE 158-957H-5N-1, 33-35 cm}

Minicore sample 158-957H-5N-1, 33-35 cm (H5), like C14, is a pyrite-silica breccia, but does not contain anhydrite. As can be seen in thin section and CT images, subangular sulfide-dominated clasts are separated from each other by 0.2 - to 5-mm-wide areas of quartz matrix (Fig. 7). In vertical CT slices, quartz appears to be interconnected along the length of the core. Again, the 1-mm spacing between horizontal slices can prevent thin $(<1 \mathrm{~mm})$ portions of matrix from showing up in the vertical cross sections. Because in horizontal slices clasts are isolated from one another by matrix, and because no single clast is the size of the length of the core, it is likely that pyrite is not connected along the full length of the core. Ranges of percents of pyrite, quartz, and large voids are $19-54 \mathrm{vol} \%, 40-76 \mathrm{vol} \%$, and 1-6 vol\%, respectively.

\section{COUPLING DATA FROM CT IMAGES WITH DATA FROM PHYSICAL PROPERTIES MEASUREMENTS}

The minicores used in this study were used for shipboard physical properties measurements. As a check on calculated relative mineral abundances, bulk and grain densities were calculated assuming densities of 5, 3, 2.65, and $1.03 \mathrm{~g} \mathrm{~cm}^{-3}$ for sulfide, anhydrite, quartz, and seawater, respectively. These calculated densities agree with shipboard measurements to within $10 \%$ (see Table 4). In addition to shipboard measurements, the minicores were used in a shore-based study of thermal properties after CT scanning was done and before having thin sections made (Rona et al., Chap. 24, this volume). Thermal conductivities were measured on a divided-bar apparatus. Minicores were saturated with distilled water, and subjected to a $10^{\circ} \mathrm{C}$ temperature difference adjusted to evenly span room temperature $\left(20^{\circ} \mathrm{C}\right)$. Measurements were made parallel to the cylindrical axes of the minicores. Accuracy of the measurements is $2 \%$, and reproducibility is $5 \%$. Details of the study, and the technique used, are given in Rona et al. (Chap. 24, this volume).

Thermal conductivities determined using the information from the CT study on mineral abundances and clast and grain associations 

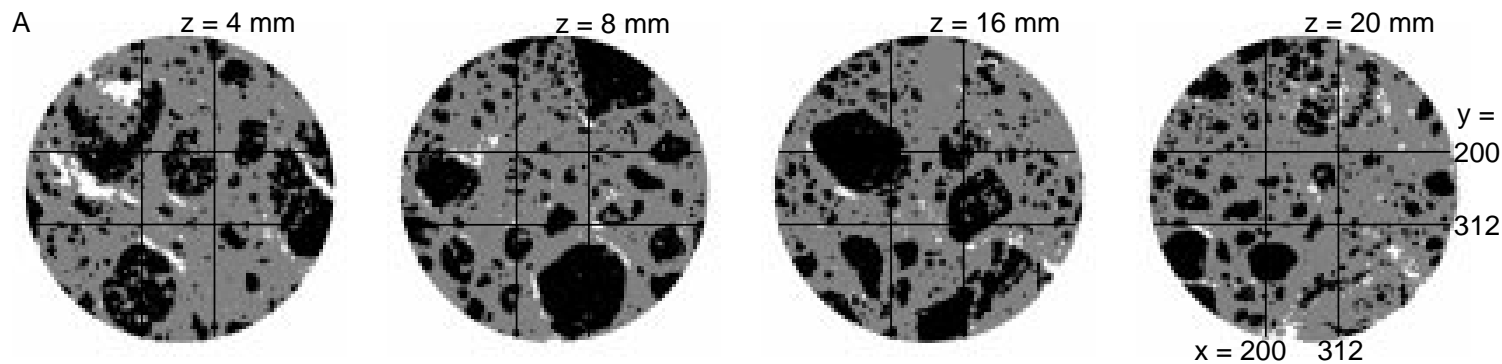

B $\quad x=200$
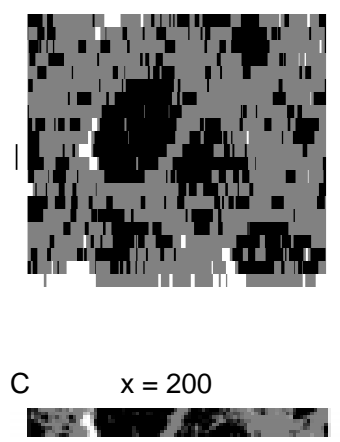

$x=312$

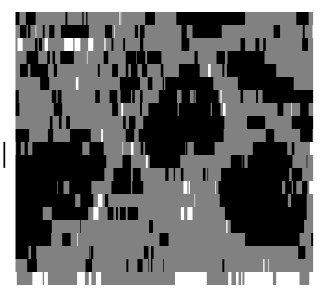

$x=312$
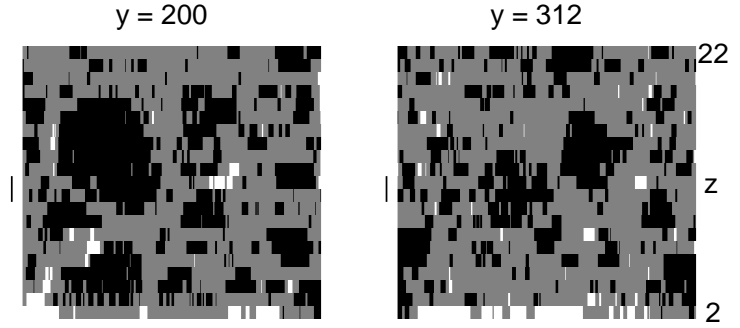

Figure 4. A. CT images taken, from left to right, from $4 \mathrm{~mm}, 8 \mathrm{~mm}, 16 \mathrm{~mm}$, and $20 \mathrm{~mm}$ above the base of minicore Sample 158-957C-7N-3 (C7). B. Vertical slices, constructed by stacking 0.1-mm-thick slices every $1 \mathrm{~mm}$, through minicore $\mathrm{C} 7 \mathrm{at} \mathrm{x}=200, \mathrm{x}=312, \mathrm{y}=200$, and $\mathrm{y}=312$ (indicated in Fig. 4A). C. Vertical slices, constructed by stacking 0.1-mm-thick slices every $0.1 \mathrm{~mm}$, through minicore $\mathrm{C} 7$ at $\mathrm{x}=200, \mathrm{x}=312, \mathrm{y}=200$, and $\mathrm{y}=312$ (indicated in Fig. $4 \mathrm{~A}$ ), providing a more detailed look at the portion of the slice shown in Figure 4B marked by the vertical line.
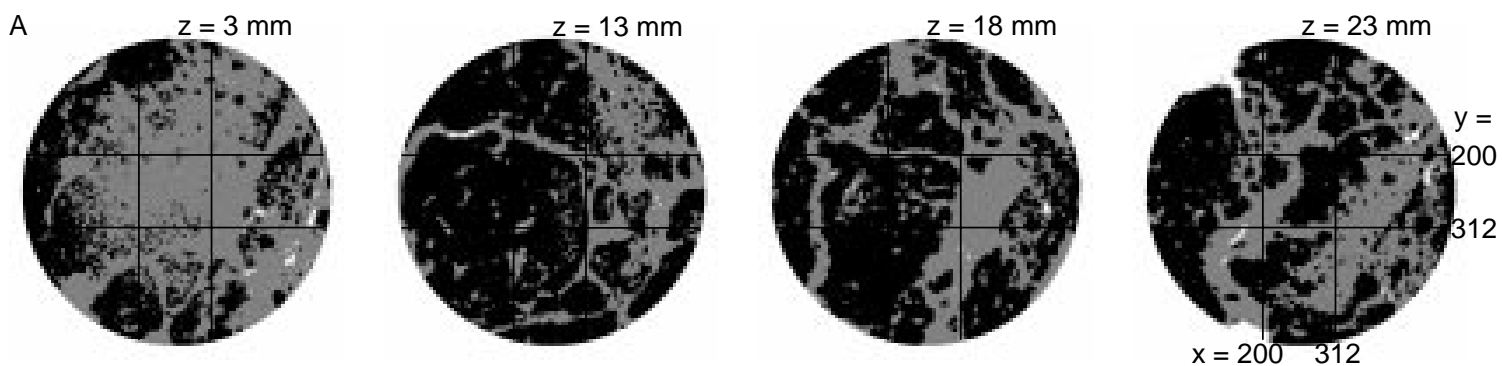

B

$x=312$
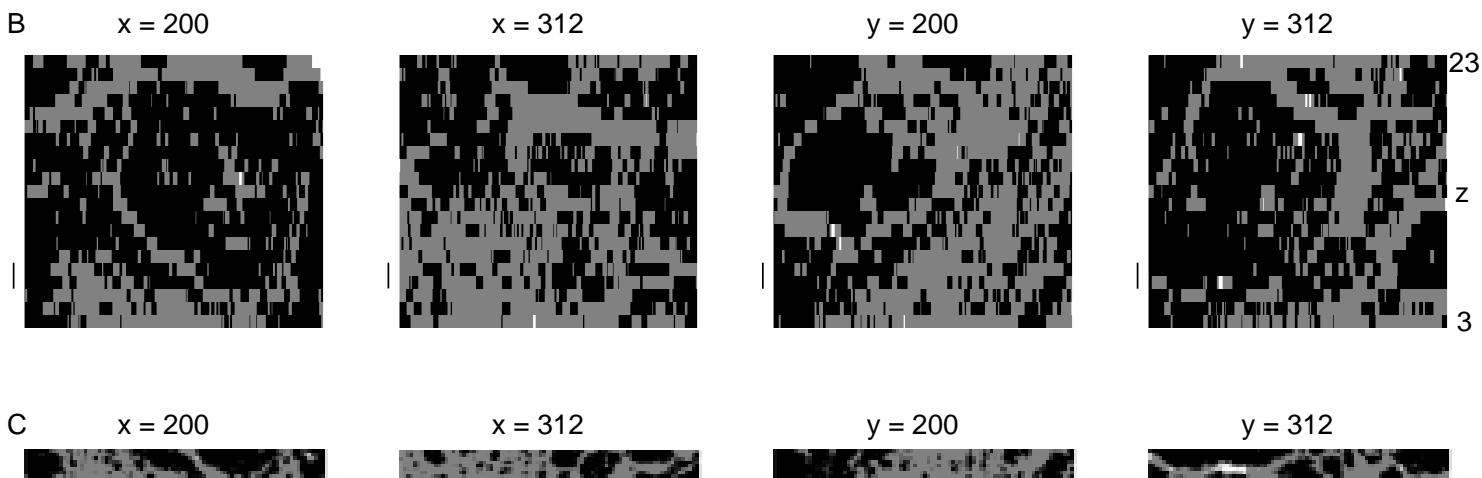

Figure 5. A. CT images taken, from left to right, from $3 \mathrm{~mm}, 13 \mathrm{~mm}, 18 \mathrm{~mm}, 23 \mathrm{~mm}$ above the base of minicore Sample 158-957C-11N-2 (C11). B. Vertical slices, constructed by stacking 0.1 -mm-thick slices every $1 \mathrm{~mm}$, through minicore $\mathrm{C} 11$ at $\mathrm{x}=200, \mathrm{x}=312, \mathrm{y}=200$, and $\mathrm{y}=312$ (indicated in Fig. $5 \mathrm{~A}$ ). C. Vertical slices, constructed by stacking 0.1 -mm-thick slices every $0.1 \mathrm{~mm}$, through minicore $\mathrm{C} 11$ at $\mathrm{x}=200, \mathrm{x}=312, \mathrm{y}=200$, and $\mathrm{y}=312$ (indicated in Fig. $5 \mathrm{~A}$ ), providing a more detailed look at the portion of the slice shown in Figure 5B marked by the vertical line. 
A
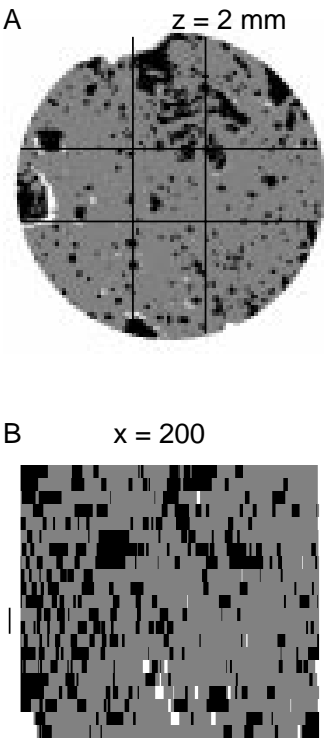

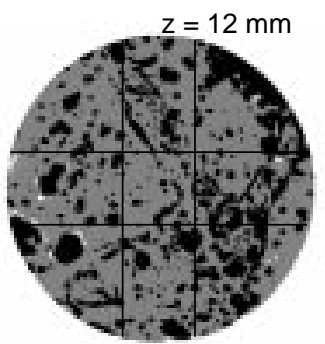

$x=312$

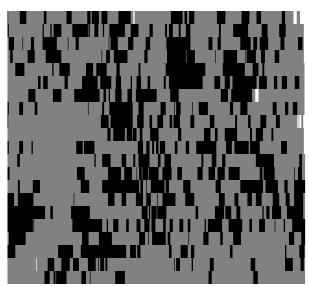

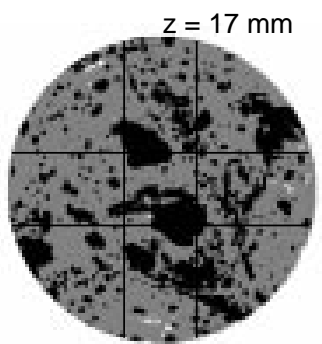

$y=200$

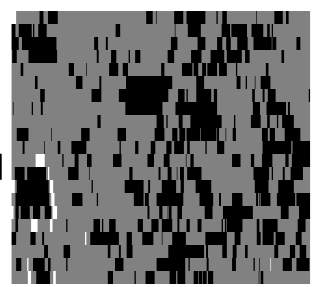

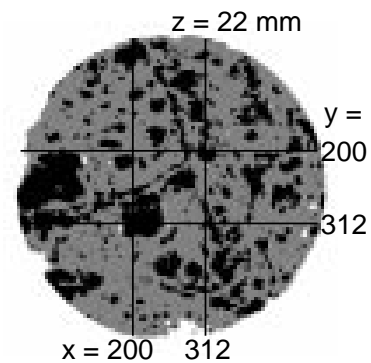

$y=312$

C

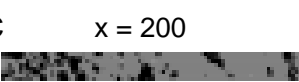

$x=312$

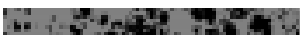

$y=200$

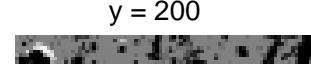

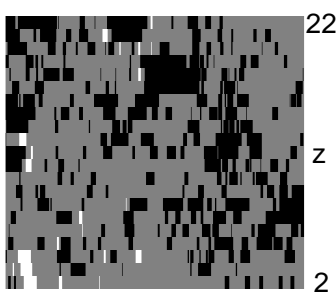

$y=312$

Figure 6. A. CT images taken, from left to right, from $2 \mathrm{~mm}, 12 \mathrm{~mm}, 17 \mathrm{~mm}$, and $22 \mathrm{~mm}$ above the base of minicore Sample 158-957C-14N-1 (C14). B. Vertical slices, constructed by stacking 0.1-mm-thick slices every $1 \mathrm{~mm}$, through minicore $\mathrm{C} 14$ at $\mathrm{x}=200$, $\mathrm{x}=312$, y = 200, and $\mathrm{y}=312$ (indicated in Fig. $6 \mathrm{~A}$ ). C. Vertical slices, constructed by stacking $0.1-\mathrm{mm}$-thick slices every $1 \mathrm{~mm}$, through minicore $\mathrm{C} 14$ at $\mathrm{x}=200, \mathrm{x}=312, \mathrm{y}=200$ and $\mathrm{y}=312$ (indicated in Fig. $6 \mathrm{~A}$ ), providing a more detailed look at the portion of the slice shown in Figure $6 \mathrm{~B}$ marked by the vertical line.
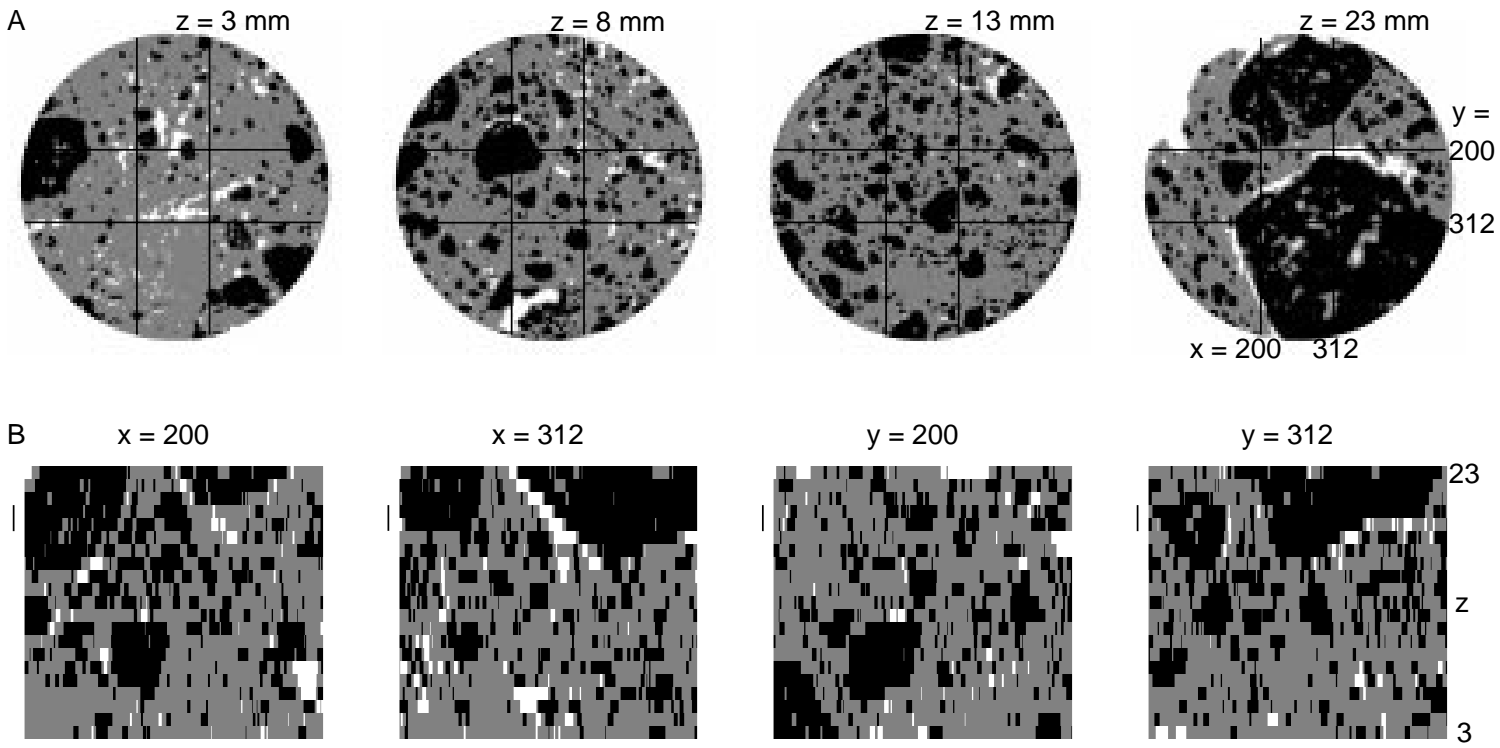

C

$x=200$

$x=312$

$y=200$

$y=312$
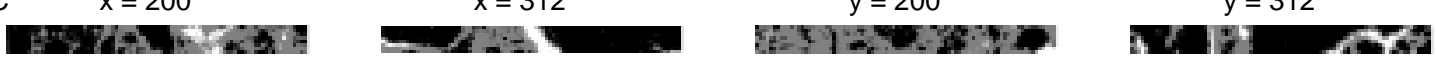

Figure 7. A. CT images taken, from left to right, from $3 \mathrm{~mm}, 8 \mathrm{~mm}, 13 \mathrm{~mm}$, and $23 \mathrm{~mm}$ above the base of minicore Sample 158-957H-5N-1 (H5). B. Vertical slices, constructed by stacking 0.1 -mm-thick slices every $1 \mathrm{~mm}$, through minicore $\mathrm{H} 5$ at $\mathrm{x}=200, \mathrm{x}=312, \mathrm{y}=200$, and $\mathrm{y}=312$ (indicated in Fig. $6 \mathrm{~A}$ ). C. Vertical slices, constructed by stacking $0.1-\mathrm{mm}$-thick slices every $1 \mathrm{~mm}$, through minicore $\mathrm{H} 5$ at $\mathrm{x}=200, \mathrm{x}=312, \mathrm{y}=200$, and $\mathrm{y}=312$ (indicated in Fig. 7A), providing a more detailed look at the portion of the slice shown in Figure 7B marked by the vertical line. 
Table 4. Comparison of bulk and grain densities for minicores from shipboard and CT studies.

\begin{tabular}{lcccc}
\hline Core, section, & $\begin{array}{c}\text { Bulk density, } \\
\text { CT study } \\
\text { interval }(\mathrm{cm})\end{array}$ & $\begin{array}{c}\text { Bulk density, } \\
\text { shipboard } \\
\left(\mathrm{g} / \mathrm{cm}^{3}\right)\end{array}$ & $\begin{array}{c}\text { Grain density, } \\
\text { CT study } \\
\left(\mathrm{g} / \mathrm{cm}^{3}\right)\end{array}$ & $\begin{array}{c}\text { Grain density, } \\
\text { shipboard } \\
\left(\mathrm{g} / \mathrm{cm}^{3}\right)\end{array}$ \\
\hline 158-957C- & & & & \\
$7 \mathrm{~N}-3$ & 3.39 & 3.49 & 3.85 & 3.96 \\
$11 \mathrm{~N}-2$ & 4.01 & 4.10 & 4.14 & 4.24 \\
$14 \mathrm{~N}-1$ & 3.38 & 3.76 & 3.47 & 3.86 \\
$158-957 \mathrm{H}-$ & & & & 3.96 \\
$5 \mathrm{~N}-1$ & 3.40 & 3.70 & 3.65 & 3.96 \\
\hline
\end{tabular}

Note: Shipboard density data from Humphris, Herzig, Miller, et al. (1996).

compare well with measured values. Two different formulas for calculating bulk thermal conductivity were used. In keeping with the observation that pyrite is not connected along the length of any of the cores imaged, neither of these formulas considers any one material being spatially continuous through the core. The first is a geometric mean model, frequently used to calculate the thermal conductivity of heterogeneous media, particularly sediments or sedimentary rocks. The bulk thermal conductivity, $\kappa_{r}$, is calculated by considering the thermal conductivities, $\kappa_{i}$, and the fractional volumes, $V_{i}$, of the $i$ constituents (Drury and Jessop, 1983):

$$
\boldsymbol{\kappa}_{r}=\prod_{i=1}^{n} \boldsymbol{\kappa}_{i}^{{ }^{V_{i}}}
$$

For the TAG minicores, measured saturated with distilled water, the constituents considered are quartz $(\kappa=7.7 \mathrm{~W} /(\mathrm{m} \cdot \mathrm{K})$; Horai, $1971)$, pyrite $(\kappa=34.2 \mathrm{~W} /(\mathrm{m} \cdot \mathrm{K})$; Roy et al., 1981), anhydrite $(\kappa=$ $5.61 \mathrm{~W} /(\mathrm{m} \cdot \mathrm{K})$; Clark, 1966), and water $(\kappa=0.609 \mathrm{~W} /(\mathrm{m} \cdot \mathrm{K})$; Chemical Rubber Company, 1988). Volume fractions of phases considered, and results of calculations, are given in Table 5, along with measured thermal conductivities.

The second model used is an equation for a random two-component mixture, suggested by Brailsford and Major (1964), where neither one of the components is spatially continuous. The bulk thermal conductivity of the rock, $\kappa_{r}$, is calculated considering the thermal conductivities of the two components, $\kappa_{l}$ and $\kappa_{2}$, and the volume fractions of the two components, $V_{l}$ and $V_{2}$ (Brailsford and Major, 1964):

$$
\begin{gathered}
\kappa_{r}=\left[\left(3 V_{1}-1\right) \kappa_{1}+\left(3 V_{2}-1\right) \kappa_{2}+\right. \\
\left.\left\{\left[\left(3 V_{1}-1\right) \kappa_{1}+\left(3 V_{2}-1\right) \kappa_{2}\right]^{2}+8 \kappa_{1} \kappa_{2}\right\}^{0.5}\right] / 4
\end{gathered}
$$

The two components considered for minicore C7 are pyrite-dominated clasts, and porous anhydrite, and, for minicore H5, pyritedominated clasts and porous quartz. Pyrite clasts were assumed to be composed of $5 \%$ quartz and $95 \%$ pyrite, with $\kappa=32.4 \mathrm{~W} /(\mathrm{m} \cdot \mathrm{K})$, calculated using Equation 2. The thermal conductivities of porous anhydrite $(\kappa=3.7 \mathrm{~W} /[\mathrm{m} \cdot \mathrm{K}])$ and porous quartz $(\kappa=6.2 \mathrm{~W} /[\mathrm{m} \cdot \mathrm{K}])$ were also calculated using Equation 2, assuming proportions of $72 \%$ anhydrite and $28 \%$ water, and $85 \%$ quartz and $15 \%$ water. These proportions assume that all pore space in these samples is present in the matrix. Calculating two components for minicores $\mathrm{C} 11$ and $\mathrm{C} 14$ was more difficult owing to the presence of 3 mineral phases plus pore space. Pyrite was considered as one component, and a combination of quartz, anhydrite, and water was considered as the second component. For minicore $\mathrm{C} 14$ this second component $(\kappa=6.5 \mathrm{~W} /[\mathrm{m} \cdot \mathrm{K}])$
Table 5. Measured thermal conductivities of minicores and calculated thermal conductivities using Equation 1.

\begin{tabular}{lcccccc}
\hline $\begin{array}{c}\text { Core, section, } \\
\text { interval }(\mathrm{cm})\end{array}$ & $\begin{array}{c}\mathrm{K} /[\mathrm{m} \cdot \mathrm{K}]) \\
\text { Measured }\end{array}$ & $\begin{array}{c}(\mathrm{W} / \mathrm{m} \cdot \mathrm{K}) \\
\text { Equation 1 }\end{array}$ & $\begin{array}{c}V_{\mathrm{i}} \\
\text { pyrite }\end{array}$ & $\begin{array}{c}V_{\mathrm{i}} \\
\text { quartz }\end{array}$ & $\begin{array}{c}V_{\mathrm{i}} \\
\text { anhydrite }\end{array}$ & $\begin{array}{c}V_{\mathrm{i}} \\
\text { water }\end{array}$ \\
\hline $\begin{array}{l}158-957 \mathrm{C}- \\
7 \mathrm{~N}-3\end{array}$ & 10.24 & 7.7 & 0.36 & 0.05 & 0.43 & 0.16 \\
$11 \mathrm{~N}-2$ & 14.95 & 15.1 & 0.57 & 0.195 & 0.19 & 0.045 \\
$14 \mathrm{~N}-1$ & 13.85 & 10.3 & 0.30 & 0.444 & 0.22 & 0.036 \\
$\begin{array}{c}158-957 \mathrm{H}- \\
5 \mathrm{~N}-1\end{array}$ & 14.00 & 10.8 & 0.38 & 0.53 & 0 & 0.09 \\
\hline
\end{tabular}

Note: Measured values are from Rona et al. (Chap. 24, this volume).

was calculated considering a mix of quartz and porous anhydrite $(\kappa=$ $4.4 \mathrm{~W} /(\mathrm{m} \cdot \mathrm{K})$, calculated using Equation 2, assuming $83 \%$ anhydrite and $17 \%$ water). For minicore $\mathrm{C} 11$ the second component $(\kappa=5.5 \mathrm{~W} /$ $[\mathrm{m} \cdot \mathrm{K}])$ was calculated considering a mix of porous quartz $(\mathrm{K}=6.3 \mathrm{~W} /$ $[\mathrm{m} \cdot \mathrm{K}]$, calculated using Equation 2 assuming $86 \%$ quartz and $14 \%$ water), and porous anhydrite $(\kappa=4.7 \mathrm{~W} /(\mathrm{m} \cdot \mathrm{K})$, calculated using Equation 2 and assuming 86\% quartz and 14\% water). Again, these proportions assume that all pore space is present in either anhydriteor quartz-dominated areas of the samples.

Results of calculations using Equation 2 are given in Table 6, and results using Equations 1 and 2 are compared to measured values of thermal conductivity in Figure 8. For all but minicore C11, thermal conductivities calculated using Equation 1 are more than 20\% less than the measured values, whereas those calculated using Equation 2 provide a good fit to measured values (within 7\%). For minicore $\mathrm{C} 11$, the thermal conductivity calculated using Equation 1 is a significantly better fit to the measured value than that calculated using Equation 2 (within $2 \%$ vs. $22 \%$ ). The simplest explanation for a need to use two different equations for minicore $\mathrm{C} 11$ vs. the other 3 is the difference in abundance of pyrite. The thermal conductivity of pyrite is more than a factor of 4 greater than quartz. The average relative amounts (averaged from vertical slices) of sulfide in minicores $\mathrm{C} 7$, $\mathrm{C} 14$, and $\mathrm{H} 5$ is $0.3-0.38$ vs. 0.58 for minicore $\mathrm{C} 11$. Given the small number of samples studied, it is difficult to speculate further on possible reasons for Equation 1 not providing as good a fit as Equation 2 for the other 3 minicores.

Given the close fits between calculated and measured thermal conductivities, it is possible to use the appropriate formulas to estimate the thermal conductivity at higher temperatures. Data from fluid inclusions in anhydrite indicate that temperatures within the TAG-1 and TAG- 2 areas were on the order of $350^{\circ} \mathrm{C}$ or greater during formation of anhydrite (Tivey et al., Chapter 14 , this volume). At $350^{\circ} \mathrm{C}$, the thermal conductivity of pyrite, quartz, anhydrite, and seawater are $\sim 20 \mathrm{~W} /(\mathrm{m} \cdot \mathrm{K})$ (Roy et al., 1981), $3.64 \mathrm{~W} /(\mathrm{m} \cdot \mathrm{K})$ (Roy et al., 1981), $3.64 \mathrm{~W} /\left(\mathrm{m} \cdot \mathrm{K}\right.$ ) (Tivey and McDuff, 1990 ; extrapolated from $20^{\circ} \mathrm{C}$ assuming a linear dependence of thermal diffusivity with $1 / \mathrm{T}[\mathrm{K}])$, and $0.43 \mathrm{~W} /(\mathrm{m} \cdot \mathrm{K})$ (Chemical Rubber Company, 1988). Using these values, and calculating the thermal conductivities of the minicores in the same method as before, using Equation 1 for minicore C11, and Equation 2 for the other minicores, the thermal conductivities at in situ temperatures within the mound are $6.1,8.7,7.1$, and $7.1 \mathrm{~W} /(\mathrm{m} \cdot \mathrm{K})$ for minicores $\mathrm{C} 7, \mathrm{C} 11, \mathrm{C} 14$, and $\mathrm{H} 5$, respectively.

These estimates of in situ thermal conductivity are needed for accurately modeling heat transport within the TAG active hydrothermal mound. For example, measured trapping temperatures in anhydrite grains are on the order of $350^{\circ} \mathrm{C}$ (Tivey et al., Chap. 14 , this volume). Sr-isotopic analyses indicate that the fluids forming the anhydrite at $\sim 350^{\circ} \mathrm{C}$ are mixtures of seawater $(57 \%$ to $99.5 \%)$ and lesser amounts of hydrothermal fluid (Mills et al., Chap. 10, this volume). Conductive heat gain is required to raise the temperatures of these fluid mixtures from $5^{\circ}-250^{\circ} \mathrm{C}$ (temperatures from mixing) to $\sim 350^{\circ} \mathrm{C}$. Tivey et al. (Chap. 14, this volume) present a simple model for achieving 
Table 6. Measured thermal conductivities of minicores, and calculated thermal conductivities using Equation 2.

\begin{tabular}{ccc}
\hline $\begin{array}{c}\kappa \\
\begin{array}{c}\text { Core, section, } \\
\text { interval }(\mathrm{cm})\end{array}\end{array}$ & $\begin{array}{c}\kappa \\
(\mathrm{W} /[\mathrm{m} \cdot \mathrm{K}])\end{array}$ & $\begin{array}{c}\mathrm{M} /[\mathrm{m} \cdot \mathrm{K}]) \\
\text { Equation } 2\end{array}$ \\
\hline $158-957 \mathrm{C}-$ & & \\
$7 \mathrm{~N}-3$ & 10.24 & 9.9 \\
$11 \mathrm{~N}-2$ & 14.95 & 18.1 \\
$14 \mathrm{~N}-1$ & 13.85 & 12.9 \\
$158-957 \mathrm{H}-$ & & \\
$5 \mathrm{~N}-1$ & 14.00 & 13.3
\end{tabular}

Note: Measured values are from Rona et al. (Chap. 24, this volume).

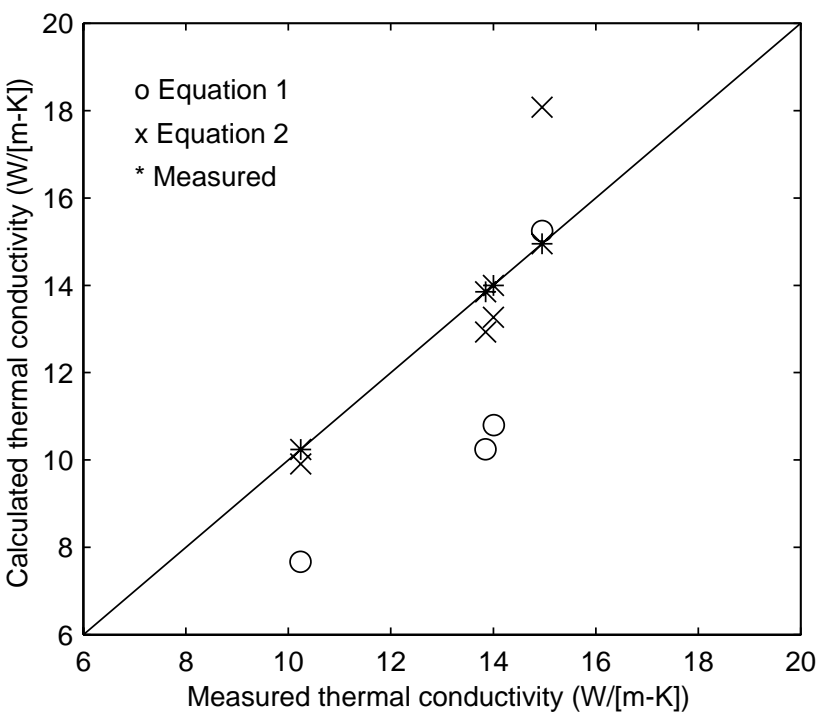

Figure 8. Comparison of measured and calculated (using Eqs. 1 and 2) thermal conductivities of minicores. Values are given in Tables 5 and 6 .

these amounts of conductive heat gain. The model considers a thickwalled hollow cylinder with an inner radius of $1 \mathrm{~cm}$, and an outer radius of either 0.1 or $1 \mathrm{~m}$. The wall of the cylinder is composed of sulfide-rich breccia with a thermal conductivity of $\sim 8 \mathrm{~W} /(\mathrm{m} \cdot \mathrm{K})$, and the outer side of the cylinder is maintained at high temperature. Given this configuration, mixtures of seawater and hydrothermal fluid can be heated to $\sim 350^{\circ} \mathrm{C}$ over a distance of 50 to $100 \mathrm{~m}$ in 4 to $9 \mathrm{hr}$ as fluid flows at rates of $<0.02$ to $0.08 \mathrm{~kg} / \mathrm{s}$.

\section{CONCLUSIONS}

$\mathrm{X}$-ray computed tomography is an excellent technique for nondestructively imaging $2.5-\mathrm{cm}$ diameter minicores at a spatial resolution of $\sim 350 \mu \mathrm{m}$. CT images allow textural relationships among clasts, matrix, and veins to be viewed in any orientation, providing a quick and efficient extrapolation of information from a single two-dimensional thin section to the scale of 2 to $3 \mathrm{~cm}$ in three dimensions. Resulting information on relative mineral abundances on the scale of the whole minicore, and on the spatial orientation of phases, can supplement data from measurements of physical properties, such as density and porosity. An example of the usefulness of the CT technique is the ability to calculate thermal conductivity at both laboratory and in situ conditions. The resulting understanding of the thermal conductivity of mound materials and of how thermal conductivity relates to pore space and mineral distribution will be useful for modeling processes of heat and mass transport within the TAG active hydrothermal mound.

\section{ACKNOWLEDGMENTS}

The help and advice of Bob Schneider is gratefully acknowledged. X-ray CT scans were done at BioImaging Research, Inc. by Greg Hoeft. Sandipa Singh provided guidance with image processing. Peter Rona kindly provided thermal conductivity data prior to its publication. The manuscript has benefited from reviews by T. Orsi and an anonymous reviewer. This work was supported by USSAC under JOI-USSSP Account No. 158-20889.

\section{REFERENCES}

Bates, R.H.T., Garden, K.L., and Peters, T.M., 1983. Overview of computerized tomography with emphasis on future developments. Proc. IEEE, 71:533-549.

Becker, K., and Von Herzen, R.P., 1996. Pre-drilling observations of conductive heat flow at the TAG active mound using Alvin. In Humphris, S.E., Herzig, P.M., Miller, D.J., et al., Proc. ODP, Init. Repts., 158: College Station, TX (Ocean Drilling Program), 23-29.

Brailsford, A.D., and Major, K.G., 1964. The thermal conductivity of aggregates of several phases, including porous materials. Brit. J. Appl. Phys., 15:313-319.

Chemical Rubber Company, 1988. Handbook of Physical Constants (69th ed.): Boca Raton, FL (CRC Press)

Clark, S.P., 1966. Thermal conductivity. In Clark, S.P. (Ed.), Handbook of Physical Constants. Mem.-Geol. Soc. Am., 97:461-482.

Deer, W.A., Howie, R.A., and Zussman, J., 1966. An Introduction to the Rock-forming Minerals: New York (Wiley)

Drury, M.J., and Jessop, A.M., 1983. The estimation of rock thermal conductivity from mineral content: an assessment of techniques. Zentralbl. Geol. Palaeontol., 1:35-48.

Edmond, J.M., Campbell, A.C., Palmer, M.R., German, C.R., Klinkhammer, G.P., Edmonds, H.N., Elderfield, H., Thompson, G., and Rona, P., 1995. Time-series studies of vent fluids from the TAG and MARK sites (1986, 1990): Mid-Atlantic Ridge: a new solution chemistry model and a mechanism for $\mathrm{Cu} / \mathrm{Zn}$ zonation in massive sulfide ore bodies. In Parson, L.M., Walker, C.L., and Dixon, D.R. (Eds.), Hydrothermal Vents and Processes. Geol. Soc. Spec. Publ. London, 87:77-86.

Evans, R., Cairns, G., and Edwards, R.N., 1993. A transient electromagnetic investigation of the TAG hydrothermal mound. Eos, 74 (Suppl.):99-100.

Evans, R.L., 1995. A seafloor gravity profile across the TAG hydrothermal mound. Eos, 76:F573.

Hannington, M.D., Thompson, G., Rona, P.A., and Scott, S.D., 1988. Gold and native copper in supergene sulfides from the Mid-Atlantic Ridge. Nature, 333:64-66.

Herzig, P.M., Hannington, M.D., Scott, S.D., Maliotis, G., Rona, P.A., and Thompson, G., 1991. Gold-rich seafloor gossans in the Troodos ophiolite and on the Mid-Atlantic Ridge. Econ. Geol., 86:1747-1755.

Horai, K., 1971. Thermal conductivity of rock-forming minerals. J. Geophys. Res., 76:1278-1308.

Humphris, Herzig, Miller, et al., 1996. Proc. ODP, Init. Repts., 158: College Station, TX (Ocean Drilling Program).

Humphris, S.E., Herzig, P.M., Miller, D.J., Alt, J.C., Becker, K., Brown, D., Brügmann, G., Chiba, H., Fouquet, Y., Gemmell, J.B., Guerin, G., Hannington, M.D., Holm, N.G., Honnorez, J.J., Itturino, G.J., Knott, R., Ludwig, R., Nakamura, K., Petersen, S., Reysenbach, A.-L., Rona, P.A., Smith, S., Sturz, A.A., Tivey, M.K., and Zhao, X., 1995. The internal structure of an active sea-floor massive sulphide deposit. Nature, 377:713-716.

Kleinrock, M.C., Humphris, S.E., and the Deep-TAG Team, 1996. Detailed structure and morphology of the TAG active hydrothermal mound and its geotectonic environment. In Humphris, S.E., Herzig, P.M., Miller, D.J., et al., Proc. ODP, Init. Repts., 158: College Station, TX (Ocean Drilling Program), 15-21.

Lalou, C., Reyss, J.L., Brichet, E., Arnold, M., Thompson, G., Fouquet, Y., and Rona, P.A., 1993. New age data for Mid-Atlantic Ridge hydrothermal sites: TAG and Snakepit geochronology revisited. J. Geophys. Res., 98:9705-9713. 
Lalou, C., Thompson, G., Arnold, M., Brichet, E., Druffel, E., and Rona, P.A., 1990. Geochronology of TAG and Snakepit hydrothermal fields, Mid-Atlantic Ridge: witness to a long and complex hydrothermal history. Earth Planet. Sci. Lett., 97:113-128.

Mills, R.A., and Elderfield, H., 1995. Rare earth element geochemistry of hydrothermal deposits from the active TAG mound, $26^{\circ} \mathrm{N}$ Mid-Atlantic Ridge. Geochim. Cosmochim. Acta, 59:3511-3524.

Mitra, A., Elderfield, H., and Greaves, M.J., 1994. Rare earth element distribution in submarine hydrothermal fluids and plumes from the Mid-Atlantic Ridge. Mar. Chem., 47:217-236.

Orsi, T.H., and Anderson, L., 1994. Bubble characteristics in gassy sediments. Trans. Gulf Coast Assoc. Geol. Soc., 44:533-540.

Rona, P.A., Hannington, M.D., Raman, C.V., Thompson, G., Tivey, M.K., Humphris, S.E., Lalou, C., and Petersen, S., 1993. Active and relict seafloor hydrothermal mineralization at the TAG hydrothermal field, MidAtlantic Ridge. Econ. Geol., 88:1987-2013.

Roy, R.F., Beck, A.E., and Touloukian, Y.S., 1981. Thermophysical properties of rocks. In Touloukian, Y.S., Judd, W.R., and Roy, R.F. (Eds.), Physical Properties of Rocks and Minerals (Vol. I-2): New York (McGrawHill), 409-502.

Thompson, G., Humphris, S.E., Schroeder, B., Sulanowska, M., and Rona, P.A., 1988. Active vents and massive sulfides at $26^{\circ} \mathrm{N}$ (TAG) and $23^{\circ} \mathrm{N}$ (Snakepit) on the Mid-Atlantic Ridge. Can. Mineral., 26:697-711.
Tivey, M.A., Rona, P.A., and Schouten, H., 1993. Reduced crustal magnetization beneath the active sulfide mound, TAG hydrothermal field, MidAtlantic Ridge $26^{\circ}$ N. Earth Planet. Sci. Lett., 115:101-115.

Tivey, M.K., Humphris, S.E., Thompson, G., Hannington, M.D., and Rona, P.A., 1995. Deducing patterns of fluid flow and mixing within the TAG active hydrothermal mound using mineralogical and geochemical data. $J$. Geophys. Res., 100:12,527-12,555.

Tivey, M.K., and McDuff, R.E., 1990. Mineral precipitation in the walls of black smoker chimneys: a quantitative model of transport and chemical reaction. J. Geophys. Res., 95:12,617-12,637.

Von Herzen, R.P., and Kirkland, J., 1993. Geoelectrical measurements using Alvin at the TAG hydrothermal site, MAR 26N. Eos, 74:99.

Date of initial receipt: 3 June 1996

Date of acceptance: 26 February 1997

Ms 158SR-226 